\title{
International Trade in Cyberspace: How to Tax Digital Goods
}

\author{
Jürgen Stehn \\ Kiel Institute for World Economics
}

\begin{abstract}
The paper discusses various possible approaches to turnover taxation in cyberspace. It shows that the main challenge of the new economy is to effectively cope with B2C international trade in digital online goods and services. However, most approaches to turnover taxation discussed in the literature give rise to several surveillance, efficiency, incentive, and identification problems. As a consequence, there seem to be only two appropriate approaches to deal with the special characteristics of international trade in cyberspace, the country-of-origin principle combined with a taxation of digital goods and services at the physical location of producers, and the community principle in combination with a withholding tax (WITHVAT).
\end{abstract}

- JEL Classifications: F 15, H 21

- Key words: International trade, Turnover taxation, Electronic commerce, Sectoral efficiency

\section{The Problem}

In 1998, the U.S. government declared a turnover tax moratorium in electronic commerce. At the same time, the governments of the EU member states heavily discussed whether the supply of electronic products over data networks should be regarded as supply of goods or supply of services. They finally agreed on the latter. As a consequence, on-line sales from non-EU suppliers to final consumers

\footnotetext{
*Corresponding address: Dr. Jürgen, Stehn Kiel Institute for World Economics, Düstern brooker Weg 120, 24105 Kiel Germany Phone: ++49 431 8814-331, Fax. ++49 431 85853, e-mail: j.stehn@ @ifw.unikiel.de

(C2003-Center for International Economics, Sejong Institution, All Rights Reserved.
} 
inside the EU, and sales from EU suppliers to consumers outside the EU are not subject to value-added taxes (VAT). In the case of on-line sales from EU suppliers to EU consumers, the VAT rate of the country of origin is applied. However, if the consumer is a taxable enterprise, the on-line transaction is taxed using the rate of the country of destination.

These two very distinct reactions to the upsurge of electronic commerce are the mirror image of the difficulties in creating an effective system of turnover taxation in cyberspace that have their roots in the wide spectrum of different turnover tax rates in OECD countries. Even in internal markets like the United States and the EU, turnover tax rates differ to a considerable extent. Varying tax rates among trading partners require border controls and border tax adjustments in order to ensure effective turnover taxation. However, border controls in borderless cyberspace are a contradiction as such. The objective of this paper is to present possible solutions to this seeming contradiction. Two obvious solutions to this contradiction will not be discussed in this paper: (1) worldwide harmonization of turnover tax rates and (2) implementation of technological advances that make worldwide surveillance of Internet transactions by national governments possible. Both of these seem to be politically unfeasible and socially undesirable.

The paper is organized as follows. The next section analyzes the advantages and disadvantages of traditional approaches to the turnover taxation of international trade in digital goods and services Section II presents and discusses some innovative proposals for turnover taxation in cyberspace. Section III draws some conclusions.

\section{Traditional Turnover Tax Systems and Internet Transactions}

\section{A. The Transitional System of the EU}

As a visible outcome of the completion of the internal market, almost all physical border controls within the EU belong to the past. In 1991, the EUCommission decided to preserve the country-of- destination principle in valueadded taxation (VAT) for a transition period from January 1, 1993, to December 31,1996 , by shifting fiscal controls from national borders to exporting and importing firms and national tax authorities. In 1997, the transitional system was put in place for an indefinite period of time because the member states could not agree on the envisaged VAT system "based on the principle of taxation of goods 
and services supplied in the member states of origin" (European Commission 1991).

By introducing a transitional system, the Commission aimed at preserving the existing border adjustment without border controls. Since it was necessary to ascertain that tax-exempted goods had in fact been exported to other member states, the former border controls were shifted into exporting and importing firms. For trade between taxable persons, this system leads to a regional tax incidence and a regional fiscal assignment according to the country-of-destination principle. Exceptions exist for farmers eligible for the flat-rate scheme, taxable persons not entitled to deduction of VAT, and public bodies. Contrary to the case under the former system of border adjustment, direct purchases of private consumers in foreign member states will, as a general rule, be taxed in the country of origin. There are, however, exceptions to this rule with regard to purchases of new vehicles and distance sales.

As regards general tax efficiency, it is obvious that the transitional system involves high administrative costs for entrepreneurs as well as tax authorities. Under the conditions of the transitional system, the cost reductions from the removal of border controls will be nowhere near the original expectations, which were estimated in the range of 8-9 billion ecus in the famous Cecchini report (Cecchini et al. 1988). It will involve additional administration costs because central controls at intra-Community borders have been replaced by various decentralized controls in importing and exporting firms.

Moreover, the current system will be nonneutral with respect to sectoral allocation if direct consumer purchases play a significant role in intra-Community trade. The reason for this nonneutrality is that the EU VAT is a pure consumption tax exempting investment goods by offering a tax return for invested intermediate goods. With a zero tax rate on investment goods, the gross and net price ratios between consumption and investment goods differ if VAT rates are not uniform across the Union (Sinn 1990).

Consider a simple model of trade between two countries, Denmark (DK) and Germany $(\mathrm{G})$, in which both countries produce a homogeneous consumption good (C) and a homogeneous investment good (I). Let $p_{c}^{D K}$ and $p_{c}^{G}$ be the producer prices of consumption goods in the two countries, $p_{I}^{D K}$ and $p_{I}^{G}$ the producer prices of investment goods, and $t_{D K}$ and $t_{G}$ the VAT rates, with $t_{D K}>t_{G}$. Free transborder trade and VAT taxation according to the pure country-of-destination principle with border controls implies 


$$
\begin{gathered}
P_{I}^{G K}=P_{I}^{G} \text { and } \\
P_{c}^{G K}=P_{c}^{G} .
\end{gathered}
$$

Due to the zero rating of investment goods and the full border adjustment in taxing consumption goods, intra-Union differences in VAT rates do not affect the relative producer prices in member states:

$$
P_{c}^{G K} / P_{I}^{G K}=P_{c}^{G} / P_{I}^{G} .
$$

However, if direct consumer purchases abroad are taxed according to the VAT rate of the country of origin, as it is the case under the conditions of the transition scheme, producer prices of consumption goods will differ between both countries as a result of tax rate differentials, whereas producer prices of investment goods will not be affected by distinct national tax regimes:

$$
\begin{gathered}
P_{C}^{G K} / P_{I}^{G K}=P_{C}^{G} / P_{I}^{G} \\
P_{C}^{G K}\left(1+t_{G K}\right)=P_{C}^{G}\left(1+t_{G}\right)
\end{gathered}
$$

Taking into account differing VAT rates in member states $\left(t_{D K}>t_{D}\right)$, (4) and (5) implies

$$
P_{c}^{D K} / P_{I}^{D K}<P_{c}^{G} / P_{I}^{G}
$$

Equation (6) shows that - under the conditions of the transitional system - direct consumer purchases abroad are driving producers of consumption goods in hightax countries to lower their producer prices according to the actual tax differential. Thus, high-tax countries have a tax-induced incentive to specialize in investment goods, low-tax countries to specialize in consumption goods. As a result of this distortion of sectoral allocation efficiency, the transitional system leads to an overall decrease in the production of consumption and investment goods in the trading partner countries, compared to a tax regime - like the pure country-ofdestination principle with border controls - that is neutral with regard to sectoral allocation.

\section{The Taxation of International Trade in Cyberspace}

The magnitude of the sectoral allocation distortion described above depends on the magnitude of direct consumer purchases. Since the special characteristics of the transition scheme guarantee an intercountry tax adjustment according to the 
pure country-of-destination principle for mail-order services and the direct purchase of automobiles, the resulting distortions might currently be relatively small. However, it can realistically be assumed that the upswing in electronic commerce via the Internet will be reflected in an upswing in direct transborder purchases by consumers leading to a further erosion of sectoral allocation efficiency. To evaluate the significance of this effect, it is necessary to distinguish between traditional and digital on-line goods.

A substantial part of business-to-consumer electronic commerce (B2C) currently consists of traditional on-line goods like books, clothing and CDs that are ordered on-line via the Internet and are delivered off-line by traditional mail or express messengers. With regard to turnover taxation, cross-border trade of such material goods could generally be treated like traditional mail-order services. In order to guarantee taxation of distance sales according to the country-ofdestination principle, the transition scheme provides that mail-order firms with a turnover of more than 100,000 euros per year in a single member state have to designate a fiscal agent in the country of destination who serves as a guarantor for the tax liabilities of the distance seller.

The designation of a guarantor serving as some kind of a "supervisor" is necessary to prevent mail-order firms located in low-tax countries from cheating. A firm could declare turnovers from a high-tax country as domestic turnovers in order to gain from tax differentials. For example, a German mail-order firm that declares a distance sale to a Swedish consumer as a domestic sale but invoices the Swedish VAT rate of 25 percent would only have to pay a VAT of 16 percent (the German rate) to the domestic fiscal authorities. As long as cross-border distance sales are relatively small and as long as there are only a few mail-order firms with significant orders from abroad, this might not pose a serious problem. However, easy access to information about foreign suppliers via the internet might make it far more attractive to order goods from abroad and might therefore increase the incentives for cheating.

As a matter of fact, a fiscal agent is only in a position to guarantee the correct taxation of imported mail-order goods if all imports are first shipped to a warehouse in the "backcountry" and then distributed to the respective consumer, as is the usual practice in the distribution of transborder sales by bigger mail-order firms in the EU. But given the huge number of on-line suppliers and the growing number of possible distribution channels, this practice will not stand the challenges of the new economy. What is more, fiscal authorities in the respective 
country of origin have only weak incentives to invest additional resources into the surveillance of transborder sales by domestic firms, since the tax funds raised have to be passed on to the respective country of destination.

The obstacles to effectively taxing Internet transactions will be even higher with regard to cross-border trade in digital on-line goods and services that are both ordered and delivered electronically. The most important products currently being sold on-line over the Internet include:

- Computer software and on-line database information: customers can access Web sites to purchase downloadable software or access electronic research databases.

- Digitized information: customers can access Web sites and rent or purchase images in digital form (literature, music, pictures) that are transmitted electronically via the Internet.

- Financial services: clients can use the Internet to trade stocks and purchase securities or to access a "cyberbank" and do remote on-line banking.

In order to guarantee the taxation of cross-border trade in digital on-line goods according to the transition scheme, Internet suppliers have to invoice the VAT rate of the respective country of destination and to funnel the tax payments to the responsible national tax authorities. Leaving aside the surveillance and incentive problems sketched above, which are also problems with regard to trade in digital on-line goods, effective taxation of digitalized goods that is in accordance with the principles of the transition scheme might be almost impossible because of serious identification problems. In contrast to traditional on-line goods that are delivered to an identifiable postal address, trade via the Internet makes it harder to pinpoint the identity and location of individual consumers or businesses engaged in taxable activities. A domain name may give no clue to the location of a site. Moreover, if plans to develop anonymous e-money bear fruit, potential taxpayers will become even harder to identify.

Because of the considerable sectoral allocation distortions and the surveillance, incentive, and identification problems that might arise if digital on-line goods are taxed according to the principles of the transition scheme, there is an urgent need to look for alternative systems of turnover taxation. A candidate often named as a successor of the transition scheme is the so-called Community principle.

\section{B. The Community Principle and International Trade in Cyberspace}

The Community principle applies the tax-credit method which is currently used 
for the taxation of domestic trade in all member states of the EU to transborder trading. This implies that exports are taxed with the rate of the country of origin and imports remain free of tax. The importer receives a tax credit from his domestic fiscal authority for the foreign tax included in the price of the imported good. If he resells the good, it is taxed at the VAT rate of the country of destination. The Community principle thus involves a regional tax incidence according to the country-of-destination principle for all goods traded between firms liable to VAT. Note that the country-of-destination principle can only be applied to firms liable to VAT. It cannot be applied to direct consumer purchases which are taxed in the country of origin. The Community principle is thus a mixed system based on both the country-of-destination as well as the country-of-origin principle.

Moreover, under this system, the resulting regional fiscal assignment is not in accordance with the country-of-destination principle, for the importer receives a tax credit from his domestic fiscal authority although the tax is levied abroad. Introduction of the Community principle would thus imply that net-exporter countries as well as high-tax countries would realize higher tax revenues than before, while net-importer countries and low-tax countries would lose tax revenue. By introducing a clearing system, the resulting revenue losses, apart from the losses due to direct consumer purchases, could be offset. The reimbursement of importer countries for tax credits accorded to their importing firms could be based not only on individual trader accounts (microeconomic clearing) but also on general trade statistics (macroeconomic clearing).

From an economic point of view, the Community principle is superior to the transitional system, for macroeconomic clearing involves fewer administrative costs than the tight network of controls induced by the transitional system. Moreover, the Community principle is advantageous because it is directly related to the credit method which is applied to internal trade in all member states of the EU.

\section{The Taxation of International Trade in Cyberspace}

Despite the advantages it would have in taxing turnovers in the "old" economy, the Community principle involves the same deficiencies as the intermediate system with regard to direct consumer imports and, therefore, to the main challenges of the new economy. First, direct consumer imports result in a distortion of sectoral allocation efficiency, i.e., equation (6) also holds for the Community principle. Second, enforcing correct bookkeeping by firms engaged in 
cross-border trade of traditional and digital on-line goods is at least as difficult as in the case of the transitional scheme.

In contrast to the transitional scheme, enforcement problems in the framework of the Community principle arise due to the fact that this principle is directly based on the general system of value-added taxation within national borders. The central pillar of this general system is that turnovers of each link in the value-added chain are taxed according to the domestic standard tax rate. Thus, every firm operating within the value-added chain has a strong incentive to demand payment of valueadded tax from its customers because otherwise it would have to bear the VAT burden itself.

In the case of cross-border trade, importers in the country of destination are responsible for the administration of tax affairs. Under the Community principle, an importing firm handles imports like deliveries by domestic firms: it pays the VAT calculated by its foreign supplier and adds the domestic VAT to its sales to domestic firms or consumers. Thus, the existence of an importer liable to VAT is crucial for the functioning of cross-border tax adjustments. If there is no importer, i.e., the goods and services are delivered directly to consumers not liable to VAT (as is the case for all digital on-line goods as well as a large fraction of traditional on-line goods) the consumers are taxed according to the country-of-origin principle. In order to guarantee taxation according to the country-of-destination principle, a solution that is compatible with the general rules of the Community principle could be - at least at first sight - to make consumers liable to VAT. In this case, consumers would be reimbursed for their VAT paid to foreign suppliers by their domestic fiscal authorities and would have to bear a VAT burden equal to the domestic VAT rate. However, this solution is only a theoretical one and would not prove feasible in practice because it requires that all consumers be forced to present a turnover declaration for foreign goods and services to their domestic fiscal authorities. Because of the huge enforcement system that would be necessary to monitor the bookkeeping of consumers, it can be realistically assumed that consumers could, without any risk, refrain from declaring their direct imports to fiscal authorities. Only in the case of direct imports from high-tax countries would they have an incentive to comply with the rules because they would gain from the negative tax differential between the home country and the country of origin.

An alternative solution that would, however, violate the general system of the Community principle could be to shift the responsibility for cross-border tax 
adjustments in the case of direct imports to foreign suppliers, as is the case under the transition scheme. However, that would give rise to the same surveillance, incentive, and identification problems discussed with regard to the transition scheme. Thus, the Community principle, too, is not an appropriate instrument to cope with the challenges of the new economy.

\section{VIVAT, CVAT, and International Trade in Cyberspace}

Given the rather complicated tax adjustments in cross-border trade that are induced by the transitional system and the Community principle, Keen and Smith (1996) proposed an alternative scheme called VIVAT (viable integrated VAT). The basic idea of their scheme is that all nation-states set the same tax rate on all sales to registered traders liable to VAT anywhere in the world. However, the VAT rate applied to final sales, i.e., to consumers and other non registered traders, remains entirely at the discretion of the nation-states. Tax paid on intermediate purchases is credited in the usual way.

Keen and Smith (1996) emphasize that VIVAT is equivalent in structural terms to a common federal VAT levied at the intermediate rate combined with a series of provincial retail sales taxes levied at a rate equal to the difference between the provincial VAT and the common intermediate rate. It is also equivalent to a common withholding tax at the intermediate rate, charged and credited at each stage, combined with a final sales tax at the rate of the country of destination (Keen 2000).

In technical and economic terms VIVAT is very similar to the Community principle because the general tax credit method of the Community principle remains unchanged in VIVAT, except for the fact that traders liable to VAT charge the intermediate rate instead of the VAT rate of the country of origin. Charging the intermediate rate, however, does not make any difference in economic terms, since the tax-credit method guarantees final taxation according to the country-ofdestination principle. Similar to the Community principle, the VIVAT system needs some form of clearing to ensure that tax collected on intermediate transborder sales is reallocated in line with the country-of-destination principle. Finally, as in the framework of the Community principle, the VIVAT system taxes direct consumer imports at the VAT rate of the country-of-origin. Since VIVAT is very similar in economic as well as technical terms to the Community principle; all the deficiencies of the Community principle with regard to the taxation of digital on-line goods and services - sectoral allocation distortions as well as 
surveillance, incentive, and identification problems - also hold for the VIVAT system.

Another alternative approach originally proposed by Varsano $(1995,1999)$ and recently advocated by McLure (2000) is the so-called CVAT (compensating VAT). Like the VIVAT system, the CVAT approach is generally based on the Community principle. The only, but nevertheless important, difference is that transborder sales to registered importers and final consumers are not charged with the VAT rate of the country of origin, but with a so-called compensatory VAT rate that is set at a single common level in all countries of the world. McLure (2000: 730) advocates setting the CVAT rate at the (weighted) average of all the nation-states participating in the system. In analogy to the Community principle, a registered importer receives a tax credit from his domestic fiscal authority for the CVAT included in the price of the imported good. If he resells the good, it is taxed at the VAT rate of the country of destination, and the importer clears the difference between paid and received tax funds with his fiscal authorities. Since the CVAT on exports is collected by foreign exporters and then directed to fiscal authorities in the country of origin, the CVAT system, like the VIVAT system and the Community principle, needs some kind of a clearing mechanism to ensure regional tax assignment according to the country-of-destination principle.

In the realm of the "old" economy, the CVAT system does not make much of a difference compared with the Community principle. The only advantage of this new approach is that vendors engaged in transborder trade would need to deal with only two tax rates: the VAT rate of their home country and the CVAT rate, and would not have to differentiate between sales to registered traders and sales to final consumers or unregistered traders.

With regard to direct consumer purchases and thus to the main challenges of the new economy, however, the differences between the Community principle and the CVAT system are more pronounced, since the CVAT rate is also applied to direct sales to consumers. As a consequence, the possibility that consumers in high-tax countries gain from international tax differentials is reduced to some extent if the CVAT rate is defined as a (weighted) average of all national VAT rates as proposed by McLure (2000).

Nevertheless, the CVAT system - like the Community principle and the VIVAT system - does not guarantee taxation of all direct sales to consumers according to the country-of-destination principle, since even under the conditions of a somewhat tightened spectrum of international tax differentials, it will still be 
attractive for consumers to buy in countries with local VAT rates not exceeding the weighted average of the club. Thus, the general reservations against the Community principle also hold for the CVAT system.

\section{The Sales Tax System and International Trade in Cyberspace}

In a sales tax system according to the U.S. model, taxes are only levied at the stage of sale to private consumers, basically at the retail and service business since most sales to the private sector are made by these firms. Due to occasional consumer purchases from wholesalers and producers, a small part of the tax revenue is also levied at preceding stages of production.

With regard to the taxation of transborder trade, a sales tax system involves the least administrative costs of all alternatives discussed so far, since under this scheme international trade between firms is free of tax. Taxes are only levied when goods are sold to private consumers in the country of destination. Thus, a sales tax system induces a regional tax incidence and a regional fiscal assignment according to the "modified" country-of-destination principle without the installation of a clearing system. With respect to transborder trade between firms there is no tax competition; only direct consumer purchases abroad are taxed in the country of origin and thus result in a tax competition between border regions.

Although a sales tax system is superior, from the perspective of the "old" economy, to all other systems of turnover taxation that are based on the countryof-destination principle because it involves the lowest administration and transaction costs and does not require a clearing mechanism, it is not an appropriate system to cope with the challenges of the new economy. Like most other systems discussed so far, the sales-tax system leads to taxation of direct consumer imports according to the tax rate of the country of origin. Thus, it involves the same efficiency, surveillance, incentive, and identification problems as the transition scheme, the Community principle, and the VIVAT system.

\section{E. The Country-of-Origin Principle and International Trade in Cyberspace}

Another option for the taxation of transborder trading is the country-of-origin principle. Under this scheme, exports are taxed at the tax rate of the country of origin; imports are free of tax. With regard to regional fiscal assignment, netexporter countries are the winners, net-importer nations the losers, compared to the country-of-destination principle. However, a clearing mechanism can act to reimburse net-importer countries. From a more technical point of view, the 
country-of-origin principle can be managed by applying the subtraction method to transborder sales. In this case, an importing firm does not get a refund for the foreign VAT paid, as it is the case in the framework of the Community principle, but deducts the purchase price of the imported good from its taxable sales revenue. However, there are some complications with this method when an imported good passes through various stages of production within the importing country, since the share of the value-added created abroad has to be recalculated from step to step. An alternative method which would prevent problems of this kind is the fictitious tax-credit method. Under this method, the importer gets no tax credit for the actual tax payment to the exporter but gets a reimbursement according to the domestic VAT rate.

In the framework of the country-of-origin principle, the fiscal neutrality of transborder trade would be abolished. Hence, the competitive position of exporters in high-tax countries would deteriorate compared to exporting firms in low-tax countries. This change in competitive advantage might influence the tax policy of member states, for countries with relatively high VAT rates would lose tax revenues due to the decreasing foreign turnover of domestic exporters and the increasing direct purchases by private consumers. Hence, it can be expected that high-tax countries would reduce their VAT rates to prevent further revenue losses, while low-tax nations would gain fiscal space to increase VAT rates. This competition between locations would finally result in a competitive adjustment of VAT rates.

However, if exchange rates were flexible between countries introducing the country-of-origin principle, tax competition would play almost no role in transborder trade. In this case, the currencies of high-tax countries would devalue according to the differences in weighted average VAT rates and consequently there would be no tax competition. To be sure, the exchange rate mechanism can only adjust for differences in the level, not for differences in the structure, of VAT rates. Given the fact that the number of VAT rates in individual EU countries is as different as their structure, the country-of-origin principle necessarily leads to tax competition, even in case of an exchange rate adjustment.

\section{The Taxation of International Trade in Cyberspace}

As regards direct consumer imports and thus to the main challenges of the new economy, the country-of-origin principle reveals several advantages over all approaches that are based on the country-of destination principle. First, the 
country-of-origin principle does not induce a distortion of sectoral allocation efficiency in transborder trade because in this system, trade in consumption and investment goods is treated equally with respect to international VAT differentials. With the fictitious tax credit method, a domestic investor who buys an investment good abroad gets a tax credit equal to the domestic VAT rate. Thus, the tax credit does not vary with the country of origin of the investment good, be it a high-tax or a low-tax country, and international tax differentials have no influence on the purchase decision of domestic investors because international competition leads to equalization of producer prices after taxes. As a consequence, in our example above, equations (4) and (5) change to

$$
\begin{gathered}
p_{I}^{G K}\left(1+t_{G K}\right)=p_{I}^{G}\left(1+t_{G}\right) \text { and } \\
p_{C}^{G K}\left(1+t_{G K}\right)=p_{C}^{G}\left(1+t_{G}\right)
\end{gathered}
$$

Combining, (7) and (8) yields

$$
p_{C}^{G K} / p_{I}^{G K}=p_{C}^{G} / p_{I}^{G}
$$

Equation (9) shows that turnover taxation according to the country-of-origin principle is neutral with regard to sectoral allocation efficiency. ${ }^{1}$

Second, the country-of-origin principle does not involve the serious surveillance problem of the systems that are based on the country-of-destination principle, since there is no need for tax adjustments at national borders. The importer, whether a firm liable for VAT or a private consumer, just pays the VAT rate of the country-of-origin and the exporter directs his tax earnings to his domestic fiscal authorities. Thus, the usual controls are only necessary at the stage of the exporting firm.

Third, since all private consumers everywhere in the world are taxed at the VAT rate of the country of origin, the identification problems of the country-of-destination system do not play any role in the framework of the country-of-origin principle.

Fourth, if the country-of-origin principle goes hand in hand with a macroeconomic clearing system, there are no disincentives for fiscal authorities abroad to correctly supervise the tax collection of domestic exporters because

\footnotetext{
${ }^{1}$ In contrast to this finding, Sinn (1990) states that the country-of-origin principle is nonneutral with respect to sectoral allocation efficiency if the (true) tax credit method is applied to transborder trade. However, applying the (true, not fictitious) tax credit method does not lead to the country-of-origin principle in the true economic sense, but to the Community principle (see Stehn 1994). Thus, Sinn mixes up the two principles.
} 
otherwise they would have to bear the tax loss induced by cheating.

However, the country-of-origin principle also reveals two deficiencies. First, in order to guarantee regional fiscal assignment according to the country-ofdestination principle, a clearing system involving high administrative costs has to be introduced. Without any clearing system, net-exporter countries as well as lowtax countries would gain tax revenues, compared to the current country-ofdestination principle. However, the member countries of the EU have rejected any change in the current assignment of VAT revenues.

Second, if the exchange rate mechanism does not work due to fixed exchange rates, as is the case among the members of the European Monetary Union, or due to the fact that the differing VAT rate structures within nation-states prevent appropriate adjustment of exchange rates, the resulting tax competition between countries joining a country-of-origin system may give rise to the relocation of footloose industries towards low-tax countries. This might not be much of a problem with regard to transborder trade in the old economy or to trade in traditional on-line goods, since in these cases relocating means building new production plants or service centers abroad, involving high transaction costs that curb the magnitude of relocation. However, relocation might become more of a problem as regards the production of digital on-line goods. It is a special characteristic of digital on-line goods that they are generally produced on a server. If all goods are taxed at the location of value-added creation - according to the basic objective of a value-added tax of the country-of-origin type - the location of an Internet server determines the height of the value-added tax. Since relocating an Internet server does not involve considerable transaction costs, there are strong incentives to transfer Internet servers to low-tax or even zero-rate countries. The relocation of servers could be partly prevented by taxing turnovers at the physical location of a firm. Since most Internet suppliers are digital branches of firms producing on-line as well as off-line goods, this would reduce the incentives to relocate to a considerable extent because transferring firm headquarters would induce high transaction costs.

\section{Potential Ways to Break the Deadlock}

\section{A. The E-Card Proposal}

In 1996 the Clinton administration proposed another approach with which to 
overcome the identification problem of destination-based VAT schemes (U.S. Dept. of the Treasury 1996). The central idea of this approach is that consumers would be forced to purchase e-cards at banks that would allow the seller to identify the country the purchase was from. Only if the consumer presented a valid e-card number, would he/she be given access to the goods and services offered via the Internet. The VAT would be calculated using the country-of-destination principle, and would be immediately collected at the time of the sale. The seller would then place the funds with a third party escrow agent who would pass on the money to the appropriate government.

Because the seller is responsible for collecting the tax funds, he assumes a prominent role in the e-card proposal. The seller's task in this approach is analogous to that of the employer's in calculating, collecting, and remitting employee payroll taxes to national fiscal authorities. Thus, the same costs of compliance and enforcement issues arise under the e-card plan as do under the collection of payroll taxes. For example, the e-commerce seller might be tempted to simply keep the tax proceeds and not funnel them to the escrow agent. This compliance problem would be aggravated due to the fact that the seller's host country would have no incentives to expand resources for monitoring and enforcement because the country of origin would not gain any turnover tax funds under the e-card plan. Thus, there could be serious difficulties in obtaining the cooperation of the host country in the case of noncompliant sellers.

With a view to the monitoring and enforcement problems, Chan (2000) advocates the establishment of an "international e-commerce taxation agency" (Chan 2000: 266) in order to keep the e-card plan alive. The tasks of this agency would be (a) to oversee the proposed e-card taxation regime and, perhaps, report to an respective international body such as the WTO, or OECD; (b) to coordinate and manage separate turnover tax schedules of the various countries, to ensure that each country receives its proper and correct share of e-commerce tax-revenues from the escrow agent; (c) to monitor and audit the activities of the escrow agent, especially with regard to the accurate and timely allocation of tax funds to the appropriate governments; and (d) to oversee and manage the wholesale distribution of e-cards.

Although an international e-commerce taxation agency could solve the monitoring and enforcement problems of the e-card proposal, the high financial burden that the creation of such a body would lay on the shoulders of the participating nations could not be justified given the general effectiveness of the e- 
card proposal. Key to the e-card plan is that the true nationality of a consumer can be identified by an e-card identification number presented to the respective ecommerce firm. However, there is no doubt that the broad spectrum of international turnover tax rates ranging between zero per cent in Oregon and 25 per cent in Sweden would give rise to a booming trade in identification numbers via the Internet offering high rents for residents in low-tax states like Oregon or Luxembourg. Since the proposed e-cards would - due to data security provisions - only provide the nationality of a consumer, consumers in high-tax countries could, without any risk, buy identification numbers from residents in low-tax countries. Thus, despite all administrative efforts, a turnover tax system based on the country-of-destination principle in combination with an e-card scheme would - at the end of the day - lead to a tax incidence according to a "lowest-tax-country principle" and would - with regard to the resulting turnover tax revenues - be very similar to the current (non)system.

\section{B. The Introduction of a Bit Tax}

The proposal of a bit tax has recently been discussed in the United States as well as in Europe. ${ }^{2}$ The bit tax is a tax on the interactive digital traffic on the Information Superhighway. The tax would apply to all digital "bits" of information that flow through telecommunications traffic lines carrying interactive digital information. The tax would be applied to the flow volume of bit data, and then collected by telecommunication carriers, satellite networks, and cable systems, which would send it directly to the appropriate government. In order to prevent double taxation, the bit tax would apply only to value-added portions of interactive digital transactions.

Introducting a bit tax instead of a turnover taxation of digital on-line goods with all its control, efficiency, incentive, and identification problems seems - at first sight - to be appealing because of the ostensible simplicity of a bit tax: a specified tax rate is applied to the volume of interactive cyberspace "traffic" travelling over lines run by telecommunications carrier companies, and the resulting tax revenues then flow directly to national governments. However, this simplicity may be more apparent than real, for the bit tax presents vexing problems of how to accurately

\footnotetext{
${ }^{2}$ Arthur J. Cordell, "New Taxes for a New Economy”, URL: http://www.usask.ca./library/gic/v2n4/ cordell/cordell.html, visited in September, 2001; Cordell (1996); Luc Soete, Karin Kamp, "The "Bit Tax': The Case for Further Research", URL: http://www.ispo.cee.be/hlcg/bittax.html, visited in June, 2001; for a critical discussion of the Pro's and Con's of a bit tax see Beck and Prinz (1997).
} 
measure the volume of data flows and how to accurately separate which data is taxable and which is not. Consequently, tax collection could either be inflated or deflated, causing unintended distortions in the e-tax base and instability in the tax system. Additionally, taxing business transactions in a different manner specifically because they are conducted by means of electronic commerce violates the principle of tax neutrality. What is more, the number of bits transferred via the Internet does not say anything about the value of the goods and services that are incorporated in the data transfer. Thus, a bit tax has the characteristics of a transportation tax rather than of a consumption tax, which leads to additional distortions in the taxation of off-line and on-line goods and services.

A distinguishing feature of the bit tax is that the entire burden of collecting and remitting the tax is borne by the carrier company. However, it is arguable that carrier companies would provide the necessary technical and labor resources to effectively perform such a function. There would also be compliance problems with regard to carrier companies. Without a central international regulatory agency that would oversee the carriers, there would be difficulties in ensuring that companies collected the correct amount of tax and accurately allocated the funds to the designated governments. Even if such an agency were created by international treaty or agreement, it seems doubtful that sovereign governments would accede to international jurisdiction and oversight over the activities of their key telecommunications companies (Chan 2000: 257). There would also be only weak incentives for the carrier company's host country to enforce bit tax regulations, since in many e-commerce transactions, the country of destination, i.e., the tax creditor, is not the carrier company's host country. Due to these deficiencies, the bit tax is not an appropriate substitute for effective turnover taxation in cyberspace.

\section{The Proposal of the European Commission}

With regard to the value-added taxation of e-commerce the European commission submitted a proposal for an amendment of the $6^{\text {th }}$ VAT Directive in June 2000 (European Commission 2000). This proposal includes the following provisions:

a. For supplies from outside the EU, the proposed provisions differentiate between direct sales to $€$ nsumers and sales to firms liable to VAT. In the case of direct sales to EU consumers, suppliers from third countries whose annual sales within the EU exceed 100,000 have to register in one EU member state that 
serves as a destination for their e-commerce activities (single registration). For taxation purposes they are then deemed to have a fixed establishment in the member state of registration and thus have to charge the VAT rate of the chosen country and to direct the tax earnings to the country's fiscal authorities. As a consequence, on-line supplies from third countries to EU consumers are taxed according to a modified country-of-origin principle.

In the case of sales to firms liable to VAT, the importing firms in the EU have to account for VAT on their purchases from third countries by using the so-called reverse charge procedure. This procedure aims at implementing taxation according to the country-of-destination principle by shifting the responsibility for border tax adjustments solely to the importing firm. It guarantees regional fiscal assignment according to the country-of-destination principle without establishing a clearinghouse system, because importers are responsible for directing tax funds from transborder sales to their domestic fiscal authorities.

b. Direct sales to EU consumers by on-line suppliers located within the EU are taxed according to the country-of-origin principle.

c. On-line trade between firms located within the EU is taxed according to the reverse charge procedure (country-of-destination principle).

d. On-line sales of EU firms to third countries are free of EU VAT.

It is obvious that the main objective of the EU Commission's proposal is to eliminate the competitive disadvantage of EU e-commerce firms compared to third-country competitors, especially the United States. Under the current legislation, the true country-of-origin principle is applied to all on-line sales to EU consumers, be they sales by EU or by third-country firms. As a consequence, sales by U.S. firms are free of turnover taxes in the U.S. due to the tax moratorium for e-commerce, whereas sales by EU firms are taxed at the VAT rate of the country of origin, ranging from 15 percent in Luxembourg to 25 percent in Sweden and Denmark. The registration procedure ("modified country-of-origin principle") would raise the VAT burden on B2C sales by third-country firms to at least to the level of Luxembourg and thus lower the competitive edge of foreign (especially American) firms.

Due to its strong focus on improving the short-term international competitiveness of e-commerce firms in the EU, the Commission's proposal would endanger the success of any international effort to build up a definite system of B2C turnover taxation that relies on transborder cooperation. As the above discussion of potential ways to break the taxation deadlock has elucidated, any 
more or less appropriate reform approach requires some sort of international agreement built upon a spirit of mutual trust. However, taking the difficulties in taxing transborder e-commerce as a platform to introduce a new international trade policy instrument, i.e., the registration of foreign firms as "domestic" firms for taxation purposes, might be regarded by competitors from abroad as protectionist effort to erect new quantitative trade barriers and might thus at least weaken the mutual trust that is necessary to agree on any efficient international approach for taxing e-commerce.

Leaving aside these (important) trade policy effects, the Commission's proposal is not an appropriate approach for the taxation of international e-commerce due to tax neutrality grounds, because it advocates turnover taxation of goods imported from one and the same country using three distinct taxation procedures, the true country-of-origin principle, the modified country-of-origin principle, and the country-of-destination principle, leading to different tax burdens. Take, for example, the purchase of U.S. digital on-line goods and services by a consumer located in a high-tax EU country like Sweden. If a Swedish consumer buys a software package at a small U.S. firm that does not exceed the Euro 100,000 threshold, his/her tax burden will be zero due to the U.S. moratorium on taxing ecommerce (true country-of-origin principle). ${ }^{3}$ If he/she buys the same software package at a larger U.S. firm that is registered, for example, in the low-tax EU country Luxembourg, his/her tax-burden will rise to 15 percent (modified countryof-origin principle). If the same consumer decides to buy the same software package produced by the same large U.S. firm via an EU importer located anywhere in the EU (because for whatever reason he/she cannot access the U.S. home page of the producer), he/she pays the Swedish VAT rate of 25 percent (country-of-destination principle).

\section{E. A Mixed System: The Community Principle and a Withholding Tax (WITHVAT)}

Another potential way to break the deadlock not yet discussed in the literature would be to preserve the country-of-destination principle in taxing e-commerce by introducing a mixed system that is based in general on a modified community principle in combination with a withholding tax on B2C e-commerce in digital online goods and services (WITHVAT). With regard to off-line and on-line trade

\footnotetext{
${ }^{3}$ If he/she buys the software package at a firm located in Oregon, it will be free of turnover tax even after the termination of the tax moratorium, because Oregon charges no sales tax.
} 
between registered traders, the taxation procedures of the WITHVAT system do not differ from those of the community principle (see section II.B. above). Exports of registered traders liable to VAT are taxed at the rate of the country of destination and imports remain free of tax. The importer who initially pays the VAT rate of the country of origin receives a tax credit from his domestic fiscal authority for the foreign tax included in the price of the imported good. If he resells the good, it is taxed at the VAT rate of the country of destination. This taxation system would lead to regional tax incidence according to the country-of-destination principle and regional fiscal assignment according to the country-of-origin principle for all goods traded between registered firms liable to VAT.

As pointed out above (section II.B.), the community principle works properly only when there is an importer who is responsible for the appropriate border tax adjustment. Thus, B2C on-line trade can only be taxed according to the community principle if there are sufficient incentives for consumers to report their digital on-line purchases to national tax authorities. In this case, consumers, instead of (nonexisting) importers, could be made liable to VAT. An incentive of this kind could be set by implementing a withholding tax on all digital on-line sales in the general framework of the community principle. Under this scheme, all suppliers of digital on-line goods would be forced to add a withholding tax that would at least be equal to the highest VAT rate of all countries participating in the transborder VAT system to any sales to consumers, be they domestic residents or buyers from abroad. In the EU, Sweden has the highest VAT rate (25 percent) of all member states. Thus, a withholding tax of 25 percent would be appropriate. To preserve the country-of-destination principle in value-added taxation, consumers would receive a refund of the difference between the withholding tax and the domestic VAT rate if they presented the respective bills to their national tax authorities. This border tax adjustment could be managed in combination with the yearly income declaration of consumers.

Introducing a WITHVAT system for the taxation of digital on-line goods would have several advantages. First, the nationality of consumers could be identified because they would have an incentive to notify their digital on-line purchases to national tax authorities in order to gain from the negative tax differential between their domestic VAT rate and the withholding tax. Second, on-line firms would have no incentive to cheat, as is the case, for example, in the transitional scheme (see Chapter B.I above) because they would not be in a position to gain from differences in national VAT rates. Third, there would be no 
distortion of sectoral allocation efficiency, since direct consumer purchases via the Internet would be taxed using the same rate (after refunding), i.e., the VAT rate of the country-of-destination, as is used for all other traded goods and services. ${ }^{4}$ Fourth, in contrast to the pure community principle, the WITHVAT system would not require the establishment of a central clearing system, since the notification of consumer purchases to national tax authorities would allow decentralized reallocation of tax funds according to the country-of-destination principle.

An obvious disadvantage of the proposed WITHVAT system is the relatively high withholding tax that would be required for it to function properly. A withholding tax rate of 25 percent could hinder the further development of trade in digital on-line goods. Although the refund mechanism would guarantee taxation according to the (lower) VAT rate of the country of destination, the mere existence of a high withholding tax as well as the paperwork that would be required to obtain an appropriate refund might drive some consumers away from on-line shopping. However, how many consumers would react this way is an empirical question that cannot be answered in advance.

\section{Conclusions: WITHVAT or What?}

This discussion of the various possible approaches of turnover taxation in cyberspace has elucidated that the main challenge to the new economy is to effectively cope with B2C transborder trade in digital on-line goods and services. However, the traditional systems of turnover taxation, which are being based on the country-of-destination principle, such as the EU transitional system, the sales tax system, the community principle, and the VIVAT and CVAT systems, give rise to several surveillance, efficiency, incentive, and identification problems in taxing B2C e-commerce and, thus, are not appropriate instruments to cope with the challenges of the New Economy. The same holds for the more innovative proposals that have been made with regard to the taxation of $\mathrm{B} 2 \mathrm{C}$ transborder trade in digital on-line goods, such as the U.S. e-card proposal, the EU Commission's modified country-of-origin proposal, or the bit tax proposal. As a consequence, there are only two appropriate approaches dealing with the special characteristics of transborder trade in cyberspace: the country-of-origin principle

\footnotetext{
${ }^{4}$ With the only exception being physical direct consumer purchases abroad.
} 
combined with a taxation of digital goods and services at the physical location of producers, and the community principle in combination with a withholding tax (WITHVAT).

The main advantage of the country-of-origin principle is that it does not require any transborder tax adjustment and that it is also a suitable and effective approach for the turnover taxation of traditional off-line and on-line goods. However, the country-of-origin principle requires an administratively burdensome central clearinghouse system in order to guarantee regional fiscal assignment according to the country-of-destination Principle as demanded by the governments of the EU member states. The main advantage of the WITHVAT approach is that it does not need a central clearinghouse system, because decentralized clearing is endogenous in the system. However, the WITHVAT approach may make consumers stay away from e-commerce and is not a suitable approach for the taxation of traditional offline and on-line goods.

\section{Acknowledgment}

The auther would like to think Marianne Keudel for her valuable research assistance and Alfred Boss, Björn chistensen, and Henning Klodt for their helpful comments.

Received August 2002, Accepted December 2002

\section{References}

Beck, H., and A. Prinz (1997). Should All the World Be Taxed? Taxation and the Internet. Intereconomics 32 (2): 87-92.

Cecchini, P., et al. (1988). The European Challenge: The Benefits of a Single Market. Wildwood House, London.

Chan, C. W. (2000). Taxation of Global E-Commerce on the Internet: The Underlying Issues and Proposed Plans. Minnesota Journal of Global Trade 9 (1): 233-268.

Cordell, A. (1996). New Taxes for a New Economy. Government Information in Canada 2 (1): $15-23$.

Cordell, A. (2001). New Taxes for a New Economy. URL: http://www.usask.ca./library/ gic/v2n4/cordell/cordell.html

European Commission (1991). Richtlinie 91/680/EWG zur Erganzung des gemeinsamen Mehrwertsteuersystems und zur Anderung der Richtlinie 77/388/EWG im Hinblick auf die Beseitigung der Steuergrenzen. Amtsblatt der Europaischen Gemeinschaften, 
No. L 376, Brussels.

European Commission (2000). Proposal for a Council Directive amending Directive 77/ 388/EEC as regards the value added tax arrangements applicable to certain services supplied by electronic mean. Brussels.

Keen, M. (2000). VIVAT, CVAT and All That: New Forms of Value-Added Tax for Federal Systems. International Monetary Fund, IMF Working Paper 00/83, Washington, D.C.

Keen, M., and S. Smith (1996). The Future of the Value Added Tax in the European Union. Economic Policy 23 (October): 375-411.

McLure, C. (2000). Implementing Subnational Value Added Taxes on Internal Trade: The Compensatory VAT (CVAT). International Tax and Public Finance 7 (6): 723-740.

Sinn, H.-W. (1990). Tax Harmonization and Tax Competition in Europe. European Economic Review 34 (2/3): 489-505.

Soete, L., and K. Kamp (2001). The Bit Tax: The Case for Further Research. URL: http: //www.ispo.cee.be/hlcg/bittax.html

Stehn, J. (1994). Turnover Taxation in the EC: Options for Future Reforms. Kiel Institute of World Economics, Kiel Working Papers 613, Kiel.

U.S. Department of the Treasury (1996). Selected Tax Policy Implications of Global Electronic Commerce. Washington, D.C.

Varsano, R. (1995). A Tributacão do Comércio Interestadual: ICMS versus ICMS Partilhado. Texto para Discussão No. 382, Istituto de Pesquisa Ecônomica Aplicada, Brasilia.

Varsano, R. (1999). Subnational Taxation and the Treatment of Interstate Trade in Brazil: Problems and a Proposed Solution. Paper presented to the World Bank's Annual Bank Conference on Development in Latin America and the Caribbean (ABCD-LAC): "Decentralization and Accountability of the Public Sector", Validivia, Chile. 